\title{
Observational analysis of the daily cycle of the planetary boundary layer in the central Amazon during a non-El Niño year and EI Niño year (GoAmazon project 2014/5)
}

\author{
Rayonil G. Carneiro ${ }^{1}$ and Gilberto Fisch ${ }^{2}$ \\ ${ }^{1}$ National Institute for Space Research (INPE), São José dos Campos, Brazil \\ ${ }^{2}$ Department of Aerospace Science and Technology, São José dos Campos, Brazil
}

Correspondence: Rayonil G. Carneiro (rayonilcarneiro@gmail.com)

Received: 17 June 2019 - Discussion started: 17 July 2019

Revised: 4 April 2020 - Accepted: 10 April 2020 - Published: 12 May 2020

\begin{abstract}
The Amazon biome contains more than half of the remaining tropical forests of the planet and has a strong impact on aspects of meteorology such as the planetary boundary layer (PBL). In this context, the objective of this study was to conduct observational evaluations of the daily cycle of the height of the PBL during its stable (night) and convective (day) phases from data that were measured and/or estimated using instruments such as a radiosonde, sodar, ceilometer, wind profiler, lidar and microwave radiometer installed in the central Amazon during 2014 (considered a typical year) and 2015 during which an intense El Niño-Southern Oscillation (ENSO) event predominated during the GoAmazon experiment. The results from the four intense observation periods (IOPs) show that during the day and night periods, independent of dry or rainy seasons, the ceilometer is the instrument that best describes the depth of the PBL when compared with in situ radiosonde measurements. Additionally, during the dry season in 2015, the ENSO substantially influenced the growth phase of the PBL, with a $15 \%$ increase in the rate compared to the same period in 2014.
\end{abstract}

\section{Introduction}

The Amazon basin covers about a third of the South American continent and extends for approximately $6.9 \times 10^{6} \mathrm{~km}^{2}$, of which about $80 \%$ is covered by tropical forests (Tanaka et al., 2014; Ghate and Kollias, 2016). The Amazon biome represents more than half of the world's remaining tropical forests and consequently has a strong impact on the climate of South America. Thus it is one of the major tropical convective regions in the global climate system (Tang et al., 2016). It provides moisture to the global hydrological cycle and energy to drive the global atmospheric circulation, with a large influence on meteorological components such as the planetary boundary layer (PBL). Understanding convective systems over the Amazon region through observations is important for understanding and simulating these systems.

In this region there is a substantial quantity of convective activity that occurs during the entire year, but there are significant seasonal differences due to annual variation in atmospheric circulation and thermodynamic structure (Marengo and Espinoza, 2016), and these wet (or rainy) and dry seasons are well-defined. In this context, during the years 2014 and 2015, in the central Amazon region, the Green Ocean Amazon (GoAmazon) project was conducted with the objective of observing the influence of the complex interaction between the pollution plume generated in the city of ManausAmazonas and clouds and vegetation (Martin et al., 2016). This project approached research questions from a multidisciplinary perspective, and one of the studied topics was the physics involved in convective processes in the Amazon with emphasis on differences between wet and dry seasons.

The PBL is a turbulent layer of the atmosphere near the surface that results from the interaction between the surface and the atmosphere. The knowledge of the properties of the PBL has important scientific and practical applications because through this understanding of the PBL operational models of weather and climate forecasting can be refined, pollutant dispersion processes can be adequately described, 
the eolic potential of a region can be objectively determined, patterns of ventilation in urban areas can be estimated and improvements in agricultural techniques can be made (Englberger and Dörnbrack, 2017). Furthermore, a more realistic representation of processes that occur in the PBL can benefit numeric models of weather forecasting with better parameterization of convection, clouds and rain (Holtslag et al., 2013). The PBL characteristics, related to surface processes, provide important information regarding the priming of the atmosphere for convective initiation (Tawfik and Dirmeyer, 2014).

Holtslag et al. (2013) state that the PBL, since it is the lowest level of the atmosphere, is in continuous interaction with the Earth's surface, with significant turbulent transfer of heat, mass and momentum. According to these authors the PBL presents, during its daily cycle, large variations in temperature, wind and other variables in response to atmospheric turbulence and convective processes that occur in a tridimensional and chaotic form on timescales that range from seconds to hours, and the length across which these events occur is between a few millimeters and the entire depth of the PBL $(1-2 \mathrm{~km})$ or more in the case of convective clouds.

Neves and Fisch (2015) emphasize that an important characteristic of the PBL is the determination of its height because it is then possible to estimate the volume into which the source of pollution will be dispersed, and this is an important parameter for modeling of atmospheric dispersion. During its daily cycle the PBL undergoes atmospheric processes generated by thermal and mechanical convection during the day and displays stable conditions at night. The height of the PBL during the atmospheric instability phase (principally during the day) is called the convective boundary layer (CBL), and that during the stable period (principally at night) is named the nocturnal boundary layer (NBL).

In this context, observational evaluation of the daily cycle of the PBL, with emphasis on the CBL and NBL, represents an important field of study since within the PBL there occur processes that have a large impact on society and the terrestrial environment. Therefore, the objective of this study was to contribute to a more thorough understanding of the daily cycle of the height of the PBL through integration and comparison of data that were measured and/or estimated using instruments such as a radiosonde, sodar, ceilometer, wind profiler, lidar and microwave radiometer installed by the GoAmazon experiment. Furthermore, this study attempted to verify if the observational methods were representative of the daily variation in the cycle of the CBL and NBL in the central Amazon during 2014 (stated as a normal year) and 2015 and to elucidate the influence of an intense El Niño-Southern Oscillation (ENSO) event that occurred in 2015/2016.

\section{Materials and method}

In order to conduct this observational study, data from the GoAmazon project 2014/5 were used. The article by Martin et al. (2016) describes the details of the experiment wherein these data were collected, its principal objectives and some results. These data were collected using the structure that was installed at a research station called T3 $\left(03^{\circ} 12^{\prime} 36^{\prime \prime} \mathrm{S}\right.$, $60^{\circ} 36^{\prime} 00^{\prime \prime} \mathrm{W}$ ), located north of the municipality of Manacapuru in the state of Amazonas, about $9.5 \mathrm{~km}$ from an urban area and about $11.5 \mathrm{~km}$ from the left bank of the Solimões River, at the confluence of the mouth of the Manacapuru River (Fig. 1) in the central region of the Amazon basin. The T3 station is located in an area of pasture, surrounded by native forest with about $35 \mathrm{~m}$ of canopy height (Martin et al., 2016).

At the experimental site of the T3 station, instruments were installed to obtain measurements of the hydrological cycle, PBL energy flux and other micrometeorological variables, and the data from these measurements are available on the web site of ARM - Climate Research Facility (https://www.arm.gov, last access: 1 June 2019). For the current study, four intense observation periods (IOPs) were defined in order to capture the peak of the rainy (February and March) and dry (September and October) seasons of 2014 and 2015. The dates for each IOP are 15 February to 31 March 2014 and 2015 for IOP1 and IOP3 and from 1 September to 15 October 2014 and 2015 for IOP2 and IOP4. For the daily cycle analysis of the PBL the sunrise was considered to be at 06:00 LT and the sunset was considered to be at 18:00 LT, not varying throughout the year.

In order to measure the height of the PBL, instruments that probe the lower troposphere including a wind profiler (WP), ceilometer, sodar, microwave radiometer profiler (MWP) and lidar were used, and these data were compared to data taken in situ obtained using radiosondes (RSs), and this method is described below.

\subsection{Radiosonde (in situ) - RS}

In this experiment, RS measurements were obtained using a system that included a DigiCORA (MW12) (Vaisala Inc., Finland) with radiosonde model RS92SVG. The RS was coupled to a meteorological balloon that had an average ascension rate of $5 \mathrm{~m} \mathrm{~s}^{-1}$, and the readings were taken at 02:00, 08:00, 14:00 and 20:00 local time (LT), and during IOP1 and IOP2 an extra RS was performed at 11:00 LT to better characterize the convective phase. From the RS measurements, the following data were measured as functions of time during a free-balloon ascent: pressure (hPa), air temperature (dry bulb) $\left({ }^{\circ} \mathrm{C}\right)$, relative humidity $(\%)$, wind velocity $\left(\mathrm{m} \mathrm{s}^{-1}\right)$ and wind direction (deg). With these measurements, other derived quantities were computed and used in this study: altitude (m), geographic position (latitude and longitude), 


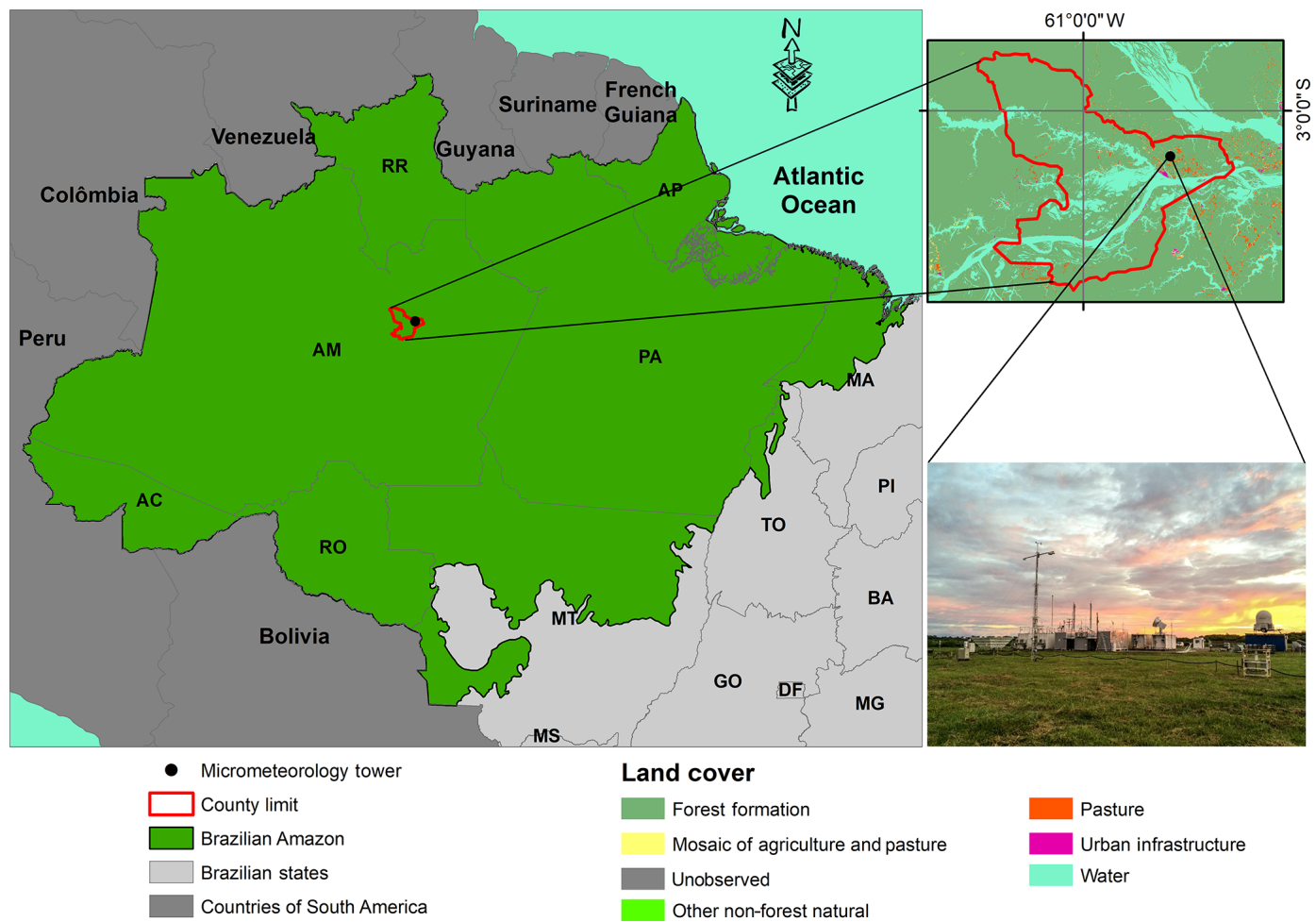

Figure 1. Location of the atmospheric measurement experiments in Manacapuru, Amazonas, Brazil.

dew point temperature $\left({ }^{\circ} \mathrm{C}\right), u$ component of wind velocity $\left(\mathrm{m} \mathrm{s}^{-1}\right)$ and $v$ component of wind velocity $\left(\mathrm{m} \mathrm{s}^{-1}\right)$.

From these data, the potential temperature $(\theta)$ and specific humidity $(q)$ were extrapolated and their vertical profiles were used for the determination of $e$ height of the PBL. At the CBL phase, the heights were identified by the vertical level where there was a systematic increase in potential temperature and a sudden reduction in specific humidity, and this method is called the profile method, as described in detail by Santos and Fisch (2007), Seidel et al. (2010), and Wang et al. (2016). However, at the NBL phase, the heights were determined by the height where the vertical $\theta$ gradient was null or less than a defined number $\left(0.01 \mathrm{~K} \mathrm{~m}^{-1}\right)$ starting from the surface. This statement relates the maximum distance from the surface where the radioactive night cooling operates, as described in detail by Santos and Fisch (2007) and Neves and Fisch (2011).

\subsection{Wind profiler (WP)}

In order to construct a wind profiler (WP) at the study site, a radio acoustic sound system (RASS) model RWP915 from Vaisala Inc. (Finland) was used for direct and continuous measurements of the PBL. The WPs are Doppler instruments used to detect the vertical wind profile, and they function at a frequency of $50 \mathrm{MHz}$ to $16 \mathrm{GHz}$. The WP-RASS installed at the study site operates at $915 \mathrm{MHz}$ to measure the wind profile. The RASS transmitter aids in the measurement of the profiles of the vertical temperature. The WP-RASS operates through transmission of electromagnetic waves in the atmosphere and measures the intensity and frequency of the backscatter of the waves, assuming that atmospheric dispersion elements are moving with the average wind profile.

Since this is an instrument that operates at a high frequency and using smaller intervals of space between layers, it is frequently used for tropospheric observations, especially for the PBL. The method used in this study is described by Wang et al. (2016), wherein the height of the PBL was estimated using the vertical profile of electromagnetic refraction of WP, where the maximum of this index occurs in the upper part of the PBL.

\subsection{Sodar}

In the study area a mini-sodar (sound detection and ranging) (model Sodar MFAS and RASS A032002, Scintec, Rottenburg, Germany) was installed. This monostatic equipment consists of an emission-receiving antenna with an area of $1.96 \mathrm{~m}^{2}$ and functions at a power of $10 \mathrm{~W}$ and a frequency of approximately $2 \mathrm{kHz}$. Using the sodar, profiles of wind velocity and direction were obtained at intervals of $30 \mathrm{~min}$ at a maximum height of $400 \mathrm{~m}$.

Through remote sensor measurement by the sodar the height of the PBL was calculated for its night phase (nocturnal boundary layer, NBL) through the determination of the maximum wind height (jet). This method was suggested 
by Neves and Fisch (2011) and showed good results for the Amazon due to its operational limit $(400 \mathrm{~m})$ and taking into account that the NBL in the region has an average depth of 100 to $300 \mathrm{~m}$.

\subsection{Lidar}

Lidar was also used to estimate the height of the PBL using a lidar model Stream Line ${ }^{\mathrm{XR}}$ from Halo Photonics (Worcestershire, UK), a single autonomous instrument from the most recent line of products from this company for atmospheric remote sensing. These systems are adequate for meteorological studies of the PBL and also for measurements of cloud cover, vertical wind profiles and air quality monitoring (Gouveia et al., 2017).

These instruments employ a laser transmitter operating at a wavelength of $1.5 \mu \mathrm{m}$, low pulse energy $(\sim 100 \mu \mathrm{J})$ and high pulse repetition frequency $(15 \mathrm{kHz})$. These instruments have full upper-hemispherical scanning capability and provide range-resolved measurements of attenuated particle backscatter coefficient and radial velocity. The fundamentals of its operation are similar to those of radar in which pulses of energy are transmitted to the atmosphere; the energy that is bounced back to the receiver is collected and measured as a resolved signal in time (Newsom, 2012).

Lidar uses a technique of heterodyne detection (method of extraction of coded information as a phase modulation and/or the frequency of a wavelength) in which the return signal is mixed with a reference laser beam (a local oscillator) of a known frequency. A computer within the instrument then processes the signal determining the Doppler frequency change using the spectrum from the signal. The energy content of the Doppler spectrums can also be used to determine attenuated backscattering.

Lidar operates in the near-infrared wavelength and is sensitive to retro-diffusion of aerosols at the micrometer scale; therefore it is capable of measuring wind speeds under clear-sky conditions with very high precision (normally $10 \mathrm{~cm} \mathrm{~s}^{-1}$ ). Lidar also possesses a superior capacity for hemispheric sweeping, thus permitting tridimensional mapping of turbulent fluxes within the PBL. Using the variance of the vertical wind speed $\left(\sigma_{w}^{2}\right)$ provided by the lidar, the method of Huang et al. (2017) was employed, where the authors define the depth of the PBL as a layer in which $\sigma_{w}^{2}$ exceeds a specific limit $\left(0.1 \mathrm{~m}^{2} \mathrm{~s}^{-2}\right)$.

\subsection{Ceilometer}

The PBL was also monitored using a ceilometer model CL31 from Vaisala Inc. (Finland). The Vaisala ceilometers are a type of lidar remote sensing instrument that operate through a maximum vertical range of $7700 \mathrm{~m}$ and register the intensity of optical backscattering at the near-infrared wavelength between 900 and $1100 \mathrm{~nm}$ through the emission of a vertical pulse that is autonomously executed. These measurements are used to produce derived products that are recorded: the height of the cloud base, the retrieval of the particle backscatter coefficient and PBL height (Wiegner et al., 2014; Shukla et al., 2014; Morris, 2016; Geiß et al., 2017; Carneiro et al., 2020). Although the ceilometer measures the reflection of the aerosol layer (thus the mixing layer height), it was assumed to be the diurnal PBL height since the entrainment zone is very shallow. Thus, throughout this paper, this information (backscatter aerosols) was assumed to be PBL height. The ceilometer is a high-temporal-resolution instrument with a measurement interval of $2 \mathrm{~s}$ and a sampling rate of $16 \mathrm{~s}$, and it is a powerful tool for measuring the height of the PBL during its daily cycle (day and night phases) to a high level of detail. The ceilometer signal results from light backscattered by particles at the atmosphere; the intensity of backscattering depends on the concentration of particles in the air (Morris, 2016). Ceilometers use pulsed diode laser lidar (light detection and ranging) technology to determine the attenuated backscatter, and the particle backscatter coefficients are obtained from these data. Subsequently the heights of the cloud base and the PBL are calculated (Wiegner et al., 2014; Kotthaus et al., 2016; Morris, 2016; Geiß et al., 2017).

The standard procedure for the PBL heights determination from Vaisala ceilometers is the software package BL-View developed by the manufacturer (see more details in Morris, 2016; Geiß et al., 2017; Geisinger et al., 2017).

\subsection{Microwave radiometer profiler (MWR)}

Data were also used from a microwave radiometer profiler model MP3000A from Radiometrics Corp., Boulder, CO, USA. This instrument provides vertical profiles of temperature, humidity and liquid water content at a sampling rate of $60 \mathrm{~s}$ and average values at intervals of approximately $5 \mathrm{~min}$. The profiles are deduced from measurements of radiance values of absolute microwaves (expressed as "brightness temperature") obtained at 12 different frequencies at intervals of 22-30 and 51-59 GHz. This type of data are useful as input into numerical models of weather forecasting which need high-resolution profiles in continuous time.

To obtain the potential temperature throughout the daily cycle, it was necessary to interpolate the pressure profiles of the RS using to the method of polynomial interpolation. Together with the MWR air temperature profiles, the daily cycle of the potential temperature profile was calculated. Thus, the height of the PBL was estimated using the profile method.

The remote sensor instruments capture multiple layers from the heights of the PBL in the transition interval of day to night (between 17:00 and 18:00 LT) shown in Fig. S1 (presented in the Supplement). However, as one of the goals of this paper is to have a complete picture of the PBL cycle, the NBL heights in this interval were neglected in Figs. 4 and 6, in order to show only the decay of the CBL convection. 
Table 1. This table presents a synthesis of the instruments used in this study, the observation periods, and temporal and spatial resolutions.

\begin{tabular}{lllllll}
\hline & RS & WP & Sodar & Ceilometer & MWR & Lidar \\
\hline $\begin{array}{l}\text { Observation } \\
\text { period }\end{array}$ & $\begin{array}{l}\text { Jan 2014 to } \\
\text { Dec 2015 }\end{array}$ & $\begin{array}{l}\text { Jan 2014 to } \\
\text { Dec 2015 }\end{array}$ & $\begin{array}{l}\text { Feb 2014 to } \\
\text { Dec 2015 }\end{array}$ & $\begin{array}{l}\text { Jan 2014 to } \\
\text { Dec 2015 }\end{array}$ & $\begin{array}{l}\text { Oct 2014 to } \\
\text { Dec 2015 }\end{array}$ & $\begin{array}{l}\text { Jan 2014 to } \\
\text { Aug 2015 }\end{array}$ \\
\hline $\begin{array}{l}\text { Variables } \\
\text { observed }\end{array}$ & $\begin{array}{l}\text { Pressure; tempera- } \\
\text { ture; humidity; } \\
\text { wind speed and } \\
\text { direction }\end{array}$ & $\begin{array}{l}\text { Wind }(u, v, w) ; \\
\text { wind direction }\end{array}$ & $\begin{array}{l}\text { Horizontal wind } \\
\text { velocity }(u, v) ; \\
\text { wind direction; } \\
\text { vertical wind } \\
\text { velocity }(w)\end{array}$ & $\begin{array}{l}\text { Height of base } \\
\text { of clouds; PBL } \\
\text { height; vertical } \\
\text { visibility }\end{array}$ & $\begin{array}{l}\text { Temperature; } \\
\text { relative }\end{array}$ & $\begin{array}{l}\text { Variation in } \\
\text { vertical } \\
\text { veloc- } \\
\text { ity }\left(\sigma_{w}^{2}\right)\end{array}$ \\
\hline $\begin{array}{l}\text { Vertical } \\
\text { resolution } \\
\text { (m) }\end{array}$ & $\sim 10$ & 10 & 10 & $\sim 100$ & 30 \\
\hline $\begin{array}{l}\text { Temporal } \\
\text { resolution }\end{array}$ & $\begin{array}{l}\text { Four to five times } \\
\text { per day }\end{array}$ & $1 \mathrm{~h}$ & 30 min & $16 \mathrm{~s}$ & $60 \mathrm{~s}$ & \\
\hline
\end{tabular}

Determination of monthly rainfall for both study years was carried out using data taken with a disdrometer model Parsivel $^{2}$ (OTT Hydromet GmbH, Germany), with a temporal resolution of $10 \mathrm{~min}$. Measurements of turbulence flows were used for the eddy covariance (EC) system composed of a three-dimensional (3-D) sonic anemometer (model WindMaster Pro, Gill Instruments Limited, Hampshire, UK) coupled with an open-path infrared gas analyzer (IRGA) (LI7500, LI-COR Inc., Lincoln, Nebraska, USA) at $10 \mathrm{~m}$ above the ground. The EC provides an estimate of the net exchange of energy and mass between the terrestrial surface and the atmosphere. The estimated flux is given by a scalar magnitude that is defined as the average of the product of the fluctuations of the vertical velocity and the concentration that is being transported. In practice, this technique consists of taking observations of variables of the product at a high frequency $(10 \mathrm{~Hz})$, and from this large number of samples of each variable the statistical covariation is calculated between them. In this manner the system provides in situ measurements of turbulent fluxes of momentum, sensible and latent heat, and carbon dioxide to the surface.

The measurements of radiation and soil heat flux were taken every 30 min using the Surface Energy Balance System (SEBS), which consists of measurements of solar and terrestrial radiation collected using radiometers, and the radiation balance by a net radiometer model CNR4/CNF4, (Kipp \& Zonen, Delft, the Netherlands) installed $2 \mathrm{~m}$ above the ground. There was a coupling of sensors measuring soil heat flux by flux plates (HFT-3, Hukseflux Thermal Sensors, Delft, the Netherlands) buried at $0.02 \mathrm{~m}$ depth in this system.

In the results obtained, the average and standard deviation values were computed for different time intervals along the PBL daily cycle (Tables 2 and 3 ). The computed Pearson's correlation coefficient $(r)$ showed values higher than 0.6 for all remote sensors related to the RS, especially for the ceilometer, which showed correlations around 0.8 . Also, a significant statistical test (Student's $t$ test with 95\%) was applied for the $45 \mathrm{~d}$ of each IOP, with 2 degrees of freedom, and the results showed that there is statistical significance between the remote sensors and RS (Tables S1 to S4 in the Supplement).

\section{Results and discussion}

Analysis of the meteorological variables revealed that accumulated precipitation was different between years (Fig. 2). The year 2014 was similar to the normal climatology (for the city of Manaus - data extracted from INMET, 2018) for the region $(2300 \mathrm{~mm})$, with a total of $2451 \mathrm{~mm}$. This high rate of rainfall can be understood as a response of the dynamic fluctuation of the nearly permanent center of convection, associated with a high rate of local evapotranspiration, which contributed to recycling of water vapor and rainfall (Nobre et al., 2009; Rocha et al., 2017). In contrast, the year 2015 registered a significant reduction (approximately 30\%) of the total rainfall in relation to the previous year, with a total accumulation of $1764 \mathrm{~mm}$, well below the normal climatological average. This reduction is associated with the occurrence of the El Niño-Southern Oscillation (ENSO) event of that year (ECMWF, 2017; Macedo and Fisch, 2018; Newman et al., 2018).

During 2014, monthly accumulated precipitation was always above $50 \mathrm{~mm}$ per month, and during representative months of IOP1 (February and March 2014) the total accumulated precipitation was $720 \mathrm{~mm}$. However, during IOP2 (September and October 2014) the total accumulated precipitation was $185 \mathrm{~mm}$, yielding a reduction of nearly $75 \%$ of accumulated precipitation during IOP1. According to Ferreira et al. (2005), this difference between the rainy and dry seasons occurs because rainfall distribution in the Amazon is very irregular, with high spatial and temporal variability. Marengo et al. (2017) provide a more detailed explanation 


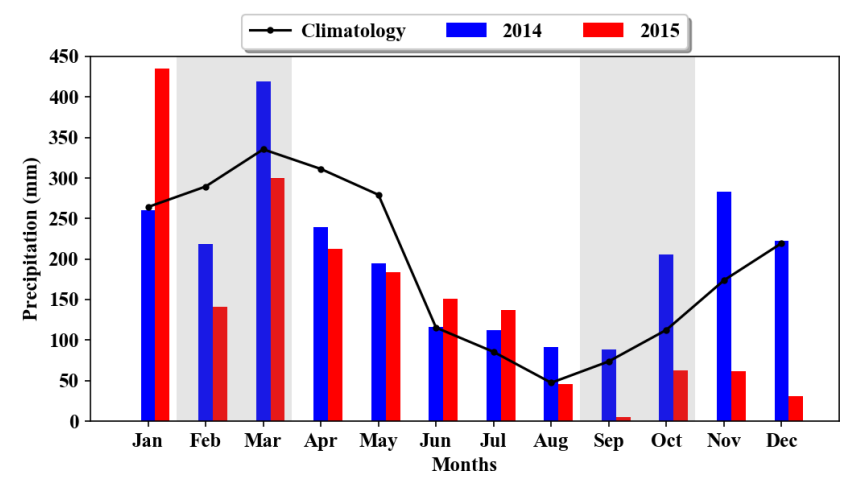

Figure 2. Distribution of accumulated monthly precipitation ( $\mathrm{mm}$ ) for the years 2014 and 2015 and the normal climatological pattern.

of this characteristic of central Amazonia and include the large-scale forcing role in the description of rainfall during the rainy and dry seasons.

While 2015 had a large reduction in rainfall, during the months of the period of intense observation of the rainy season (IOP3) the accumulated precipitation was $398 \mathrm{~mm}$, representing a reduction of approximately $50 \%$ of the total accumulated precipitation during the rainy season of 2014 (IOP1). During IOP4, the total accumulated precipitation was well below the normal climatological value, as well as in comparison to the same period in 2014 (IOP2), with a total registered precipitation of $68 \mathrm{~mm}$, a reduction of approximately $65 \%$ compared to IOP 2 . This occurred due to the EN event being more intense during these months (ECMWF, 2017; Newman et al., 2018). The ENSO event (2015/2016) was considered one of the most intense in recent years, with an intensity similar to that which occurred during 1982/83 and 1997/98 (ECMWF, 2017).

\subsection{Typical year (2014)}

Daily cycles of 30 min averages of the components of the balance of energy are presented in Fig. 3 for IOP1 (Fig. 3a) and IOP2 (Fig. 3b) for 2014. The shaded area for Fig. 3 which represents the standard deviations values was computed for each 30 min time interval. It is also shown in Figs. 4 to 6.

In these figures, the radiation balance $\left(R_{\mathrm{n}}\right)$ had positive values between $06: 00$ and 18:00 LT, with $455 \mathrm{~W} \mathrm{~m}^{-2}$ for IOP1 at 12:00 LT, and IOP2 had greater intensity of $R_{\mathrm{n}}$ with $534.5 \mathrm{~W} \mathrm{~m}^{-2}$ at 11:00 LT.

The latent heat flux $(L E)$ showed that the majority of the available net radiation (daytime conditions) was used for this flux. Both periods had similar maximum values, with 355.9 (IOP1) and $350 \mathrm{~W} \mathrm{~m}^{-2}$ (IOP2) at 12:00 LT. However, there was a reduction of net radiation converted into $L E$ between the periods, with $75 \%$ in IOP1 and $66 \%$ in IOP2. Since IOP2 refers to the dry season in the region, this presented lower water availability in the system (surface-atmosphere), which resulted in the lowest $L E / R_{\mathrm{n}}$ partition in comparison to IOP1.
In the Amazon, especially during the rainy season, only a small fraction of $R_{\mathrm{n}}$ (about $10 \%$ ) is transformed into sensible heat flux $(H)$, and this maximum of $52 \mathrm{~W} \mathrm{~m}^{-2}$ occurred at 10:30 LT during IOP1, while for IOP2, due to lower precipitation values and soil moisture deficit, there was an increase of $21 \%$ in the fraction of $R_{\mathrm{n}}$ transformed into $H$, with a maximum of $112.8 \mathrm{~W} \mathrm{~m}^{-2}$ at 12:00 LT.

Nevertheless, only a small percentage of $R_{\mathrm{n}}$ is converted into heat flux in the soil $(G)$, with a maximum of $50 \mathrm{~W} \mathrm{~m}^{-2}$ for both IOPs. These results showed that independent of the season, this flux is always low and is limited to about $5 \%$ of the total available energy.

Figure 4 shows the hourly average of the heights of the PBL for the IOP1 (Fig. 4a) and IOP2 (Fig. 4b), and Table 2 shows standard deviations values in different time intervals along the PBL daily cycle. The sunrise and sunset times were marked by the vertical lines of 06:00 and 18:00 LT, respectively, since the study area is close to the Equator line and there are not changes at these times. The RS (in situ measurements) was considered the truth depth of the boundary layer, while the others presented were estimated by remote sensing.

During the phase in which the NBL is formed (between 00:00 and 06:00 LT), IOP1 showed small vertical oscillations of its depth due to the occurrence of sporadic rainfall (Fig. 4a). The results obtained from the ceilometer between 00:00 and 03:00 LT showed that the depth of the PBL varied between 180 and $280 \mathrm{~m}$, and after 04:00 LT there was an increase in the maximum height to $350 \mathrm{~m}$, which was reduced in the following hours to $275 \mathrm{~m}$ by 06:00 LT (sunrise).

The measurements made with the WP also showed some oscillations in the height of the NBL, with a reduction in height between 00:00 and 02:00 LT from 280 to $250 \mathrm{~m}$ and then an increase to a maximum of $350 \mathrm{~m}$ at 04:00 LT, remaining constant until 06:00 LT. The sodar results during this interval showed lower variation in NBL depth during this same interval. The variation observed from the measurements by the different sensors is related to intermittent mechanical turbulence which could be the result of the presence of clouds and rain on some days and not on others, thus provoking an increase in wind variability during the night, which has the effect of deepening the NBL. However, in this same interval during IOP2 (Fig. 4b) the NBL was very stable with an average height of $250 \mathrm{~m}$ for all sensors (ceilometer, WP, sodar, MWR and lidar), thus corroborating the explanation of the influence of rainfall on the determination of variability of depth of the NBL.

The results found for the height of the NBL were similar to those reported by Neves and Fisch (2011), in a study using sodar in the southwestern Amazon, where the authors observed NBL heights varying from 150 to $329 \mathrm{~m}$. However, Acevedo et al. (2004), also studying in a pasture site in the Amazon (in Santarém-PA), observed lower NBL heights than those from the current study (between 50 and $150 \mathrm{~m}$ ), and this difference occurs because of different geographic condi- 


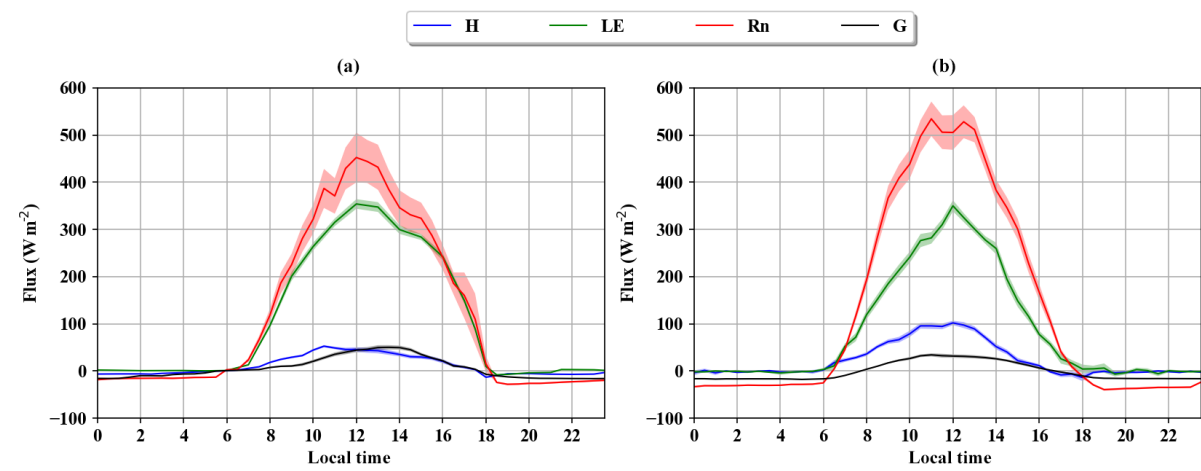

Figure 3. Average daily cycle of the radiation balance $\left(R_{\mathrm{n}}\right)\left(\mathrm{W} \mathrm{m}^{-2}\right)$, sensible heat flux $(H)\left(\mathrm{W} \mathrm{m}^{-2}\right)$, latent heat flux $(L E)\left(\mathrm{W} \mathrm{m}^{-2}\right)$ and soil heat flux $(G)\left(\mathrm{W} \mathrm{m}^{-2}\right)$ during IOP1 (a) and IOP2 (b). The shaded area represents the standard deviation.
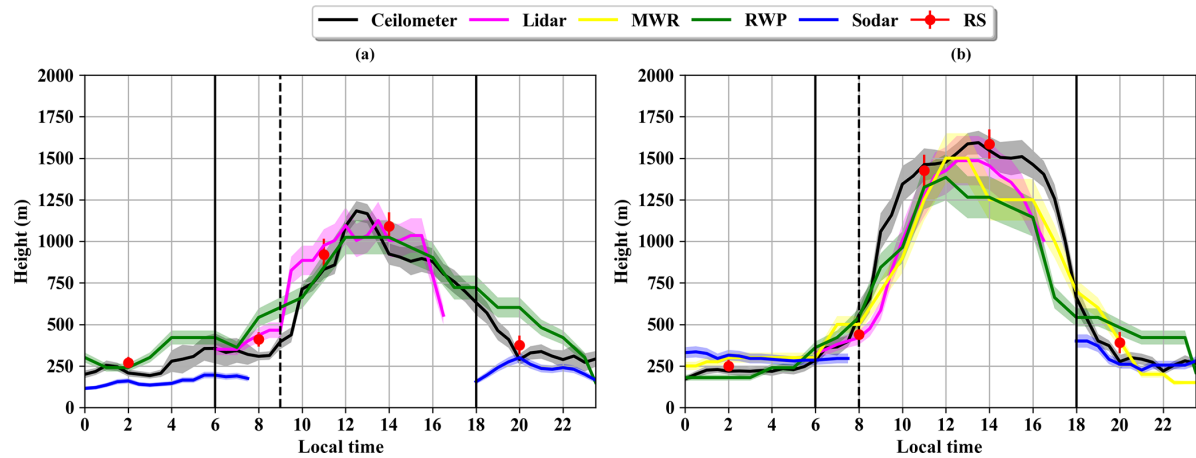

Figure 4. Daily cycle of the height of the PBL during the IOP1 (a) and IOP2 (b) experimental periods. The vertical lines represent sunrise (06:00 LT), sunset (18:00 LT) (full line) and NBL erosion (dashed line). The shaded area represents the standard deviation.

tions (influence of river breeze, fog formation, etc.). As an example of these influences, in the Santarém region the authors observed several cases of formation of fog during the night, which was not observed at the pasture site in Rondônia (see Neves and Fisch, 2015) or at T3 the site.

The phase of the erosion of the NBL according to Stull (1988) begins after sunrise (at 06:00 LT in the Amazon), and the complete erosion of the NBL occurs when the whole layer is mixed. The potential vertical gradient is almost null and as a consequence there is a high growth rate (above $100 \mathrm{~m} \mathrm{~h}^{-1}$ ). Thus, during this phase there are still several layers. In IOP1 (Fig. 4a), the erosion phase occurred $3 \mathrm{~h}$ after sunrise, where it was observed that in the first hours of this phase there is no increase in the PBL depth. Only after 08:00 LT did an increase in PBL height occur (average rate of $22.8 \mathrm{~m} \mathrm{~h}^{-1}$ ). This occurs due to a lower $H$ flux (Fig. 3a), which causes the erosion of the NBL to progress slowly, and total erosion occurs only at 09:00 LT when the average rate is $102 \mathrm{~m} \mathrm{~h}^{-1}$.

In contrast, in the IOP2 (Fig. 4b), as a function of greater stability of the NBL and the positive values of $R_{\mathrm{n}}$ and $H$ occurring earlier, initial erosion of the NBL begins at 06:00 LT, and there is a rapid increase in the depth of the PBL compared to IOP1. This increase continues in the subsequent hours at a rapid rate of $70.8 \mathrm{~m} \mathrm{~h}^{-1}$, which causes the NBL to be completely eroded by 08:00 LT. This result demonstrates that the erosion of the NBL in this region is conditioned by greater availability of energy in the early hours of the morning and by how much of this energy will be used for heating of the atmosphere $(H)$.

The transition from nighttime to daytime is very complex. Although the $H$ has become positive (thus heating the atmosphere), this amount of energy did not completely warm the atmosphere and erode the NBL (see Figs. S3 and S4 in the Supplement).

In IOP1, after complete erosion of the NBL the development phase of the convective boundary layer (CBL) begins, and due to the slow erosion of the NBL the growth of the CBL begins at 11:00 LT with a typical height of $850 \mathrm{~m}$ and an average increase of $102 \mathrm{~m} \mathrm{~h}^{-1}$, until it reaches its greatest depth at $1180 \mathrm{~m}$ at 13:00 LT. However, soon after the maximum is registered, the CBL presents a small reduction in depth $\left(13.3 \mathrm{~m} \mathrm{~h}^{-1}\right)$, due to the low value of $H$, which did not exceed $50 \mathrm{~W} \mathrm{~m}^{-2}$. This surface flux, added to the entrainment flux at the top of the CBL, was not sufficient to maintain turbulence in this layer, which showed a reduction after this time. 
Table 2. Standard deviation calculated for PBL height measurements of instruments at different intervals of the daily cycle.

\begin{tabular}{|c|c|c|c|c|}
\hline \multicolumn{5}{|c|}{$\sigma-$ IOP1 (15 February to 31 March 2014) } \\
\hline Hours & 00:00-06:00 LT & 06:00-09:00 LT & 09:00-18:00 LT & 18:00-23:00 LT \\
\hline Ceilometer & 38.2 & 59.0 & 61.7 & 53.7 \\
\hline Lidar & $\mathrm{X}$ & 49.2 & 92.0 & $\mathrm{X}$ \\
\hline MWR & $X$ & X & X & $\mathrm{X}$ \\
\hline RWP & 32.5 & 45.3 & 86.3 & 56.1 \\
\hline Sodar & 27.5 & X & X & 27.0 \\
\hline \multicolumn{5}{|c|}{$\sigma-$ IOP2 (1 September to 15 October 2014) } \\
\hline Hours & 00:00-06:00 LT & 06:00-09:00 LT & 09:00-18:00 LT & 18:00-23:00 LT \\
\hline Ceilometer & 22.2 & 52.5 & 86.4 & 38.4 \\
\hline Lidar & X & 49.5 & 97.1 & $\mathrm{X}$ \\
\hline MWR & 28.7 & 46.6 & 102.3 & 34.3 \\
\hline RWP & 20.8 & 58.1 & 110.2 & 44.4 \\
\hline Sodar & 30.6 & $\mathrm{X}$ & $\mathrm{X}$ & 29.8 \\
\hline
\end{tabular}

During IOP2, with the NBL being rapidly degraded, the CBL that subsequently formed had a more rapid development, with an average growth rate of $175.2 \mathrm{~m} \mathrm{~h}^{-1}$. The CBL had a more prolonged phase, with the maximum depth of $1590 \mathrm{~m}$ registered at 13:30 LT. After this maximum of the CBL there was a slight reduction in its growth rate $\left(-39.2 \mathrm{~m} \mathrm{~h}^{-1}\right)$ until 17:30 LT, when $H$ returned to a null value. This depth is similar to that reported by Fisch et al. (2004) in a study of the CBL in a pasture in Rondônia in the southwestern Amazon, where the authors observed a maximum depth of $1650 \mathrm{~m}$ in the dry season. Neves and Fisch (2015) also observed in Rondônia that in the initial formation of the CBL during the dry season there was very rapid growth between 08:00 and 11:00 LT, with maximum heights of about $1500 \mathrm{~m}$ at 14:00 LT.

\subsection{El Niño year (2015)}

The energy fluxes for IOP3 (Fig. 5a) and IOP4 (Fig. 5b) show that during the 2015 rainy season, $R_{\mathrm{n}}$ IOP3 behaved in an analogous manner as in the rainy season of 2014 (IOP1), with a maximum of $488 \mathrm{~W} \mathrm{~m}^{-2}$ at 12:00 LT. However, during the dry season of 2015 (IOP4) there was an increase in intensity compared to IOP2, with maximum $R_{\mathrm{n}}$ equal to $555.2 \mathrm{~W} \mathrm{~m}^{-2}$ at 12:00 LT. This greater flux of net radiation to the surface will be converted into heat flux, meaning that there is greater energy available during the dry season of 2015 compared to that of 2014 due to less cloud cover, a common characteristic in years with ENSO events (Macedo and Fisch, 2018).

The $L E$ registered a maximum of $310 \mathrm{~W} \mathrm{~m}^{-2}$ during IOP3 at 12:00 LT. This result represented $65 \%$ of the partitioning of $R_{\mathrm{n}}$. These results are within the range of results for $L E$ in this region, for which $70 \%$ of $R_{\mathrm{n}}$ is generally converted into LE (Von Randow et al., 2004; Andrade et al., 2009).
Due to the low the low water availability during IOP4, there was a reduction in the partitioning of $R_{\mathrm{n}}$ into the $L E$ flux, only about $35 \%$ in comparison with IOP3, resulting in a reduction of more than $50 \%$. The maximum $L E$ registered was at 12:00 LT and was $179 \mathrm{~W} \mathrm{~m}^{-2}$, while during IOP3 just $17 \%$ of $R_{\mathrm{n}}$ was converted into $H$, with a maximum $H$ of $86 \mathrm{~W} \mathrm{~m}^{-2}$ observed at 13:00 LT. During IOP4, $H$ had larger averages, and $60 \%$ of $R_{\mathrm{n}}$ was converted into $H$, with a maximum of $280 \mathrm{~W} \mathrm{~m}^{-2}$ at 12:00 LT. Furthermore, in 2015 during IOP3 and IOP4, only a small percentage of $R_{\mathrm{n}}$ was converted into $G$, with a maximum of $40.0 \mathrm{~W} \mathrm{~m}^{-2}$ in IOP3 and $50.0 \mathrm{~W} \mathrm{~m}^{-2}$ in IOP4, both at 12:00 LT.

The daily cycle of CBL during IOP3 (Fig. 6a), as well as in IOP1, showed vertical oscillations of the NBL's height (between 00:00 and 06:00 LT) of $200 \mathrm{~m}$ (00:30 LT) to $375 \mathrm{~m}$ (03:00 LT). The WP and the sodar yielded lower depths than the ceilometer and the MWR. However, during IOP4 (Fig. 6b) the NBL was more stable, with an average height of $250 \mathrm{~m}$, similar to what was observed during IOP2. The result from 00:00 to 06:00 LT confirms that in the Amazon region the NBL is more stable during the dry season compared to the rainy season, when it has larger variation in its depth. Table 3 shows standard deviation values in the different time intervals.

The IOP3 demonstrated a similar erosion pattern for the NBL to that observed during IOP1, with the NBL still established between 06:00 and 08:00 LT. From this time onward there was an increase in depth of the CBL with an average growth rate of $19.6 \mathrm{~m} \mathrm{~h}^{-1}$. In this manner, just as in IOP1, the erosion of the NBL during IOP3 occurred slowly, with total degradation at 09:00 LT. This result is similar to that which was observed during the same phase in IOP1, where the NBL was less stable and together with lower availability of energy at the surface caused a slower erosion of the NBL. 


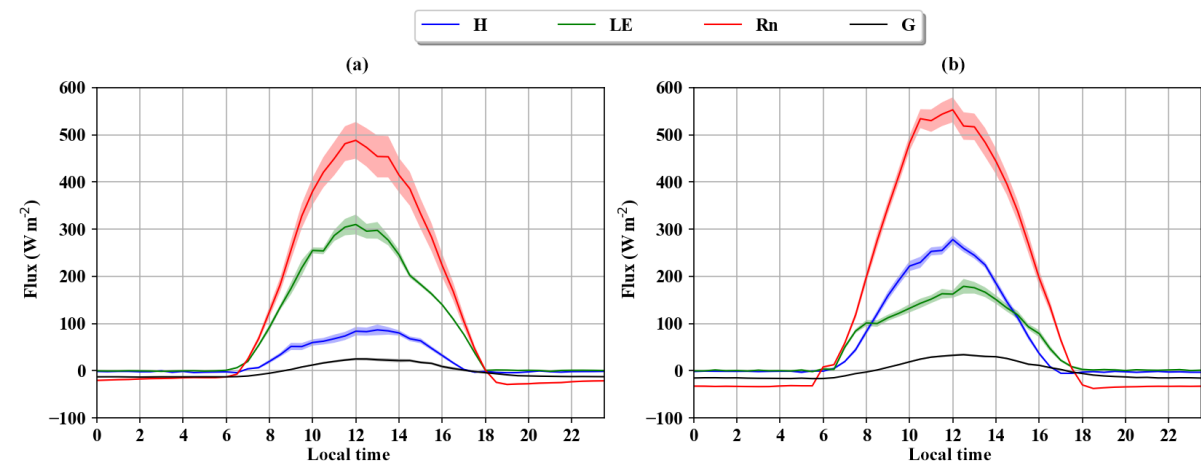

Figure 5. Average of the daily cycle of net radiation $\left(R_{\mathrm{n}}\right)\left(\mathrm{W} \mathrm{m}^{-2}\right)$, sensible heat flux $(H)\left(\mathrm{W} \mathrm{m}^{-2}\right)$, latent heat flux $(L E)\left(\mathrm{W} \mathrm{m}^{-2}\right)$ and soil heat flux $(G)\left(\mathrm{W} \mathrm{m}^{-2}\right)$ in the study region during IOP3 (a) and IOP4 (b). The shaded area represents the standard deviation.
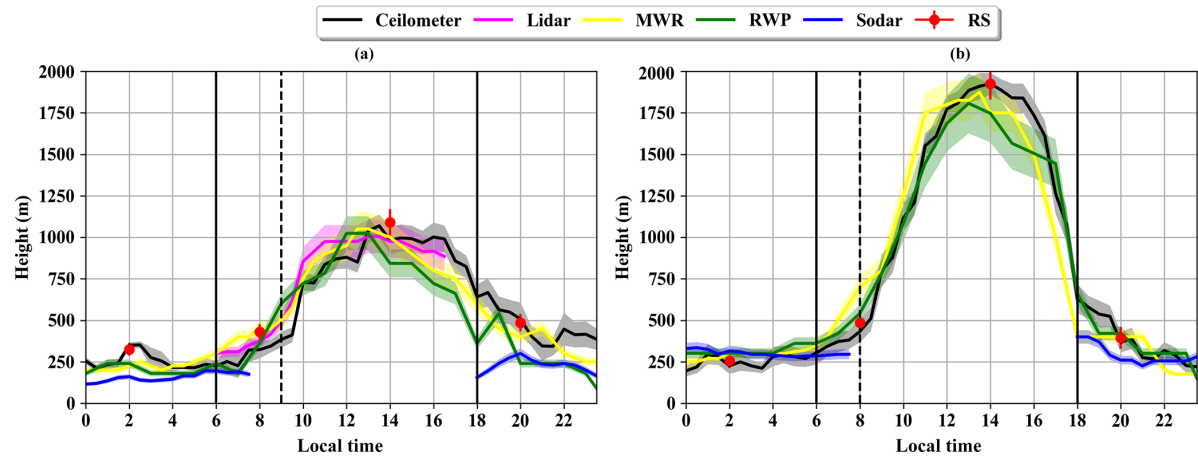

Figure 6. Daily cycle of the height of the PBL during the IOP3 (a) and IOP4 (b) experimental periods. The vertical lines represent sunrise (06:00 LT), sunset (18:00 LT) (full line) and NBL erosion (dashed line). The shaded area represents the standard deviation.

However, the erosion phase during IOP4, in response to an increase in $R_{\mathrm{n}}$ and $H$, occurred earlier (06:00 LT). Additionally, during the dry season of 2015 , the rate of ascension was higher during the subsequent hours and reached $76.1 \mathrm{~m} \mathrm{~h}^{-1}$, such that the NBL was completely eroded at 08:00 LT.

The development during IOP3 occurs in an analogous manner to that observed during IOP1, with weak vertical development of the maximum depth. At 10:00 LT the CBL begins to develop and has a height of $830 \mathrm{~m}$ and a growth rate of $100.3 \mathrm{~m} \mathrm{~h}^{-1}$, reaching a maximum depth of $1069 \mathrm{~m}$ (13:30 LT), demonstrating a shallower CBL during the wet season. However, in contrast to IOP1, IOP3 had a CBL established during the entire evening period, probably as a function of lower frequency of rainfall. IOP4, during the 2015 dry season, had greater development of convection after erosion at 08:00 LT, with a high growth rate of $193 \mathrm{~m} \mathrm{~h}^{-1}$, and at 11:00 LT the CBL was completely established. With the CBL established as a result of greater heating of the atmosphere by $H$, there was greater depth of the CBL, reaching a maximum of $1925 \mathrm{~m}$ at 14:00 LT, and this was influenced by the strong EN event, which intensified the dry season in the region and caused the highest values of $H$. This caused greater thermal convection in the development of the CBL, which increased its depth by $21 \%$ in relation to that observed in IOP2. This maximum depth of the CBL during IOP4 is not commonly found in studies conducted in the Amazon region before; however Lyra et al. (2003), using radiosonde data, reported a maximum height of $2200 \mathrm{~m}$ during the dry season of 1994 in Rondônia.

\section{Conclusions}

During the four IOPs the results show that during daytime and nighttime intervals, independent of weather conditions, the ceilometer is a promising sensor with good accuracy for direct and continuous measurement of the height of the PBL (which on average ranged from $250 \mathrm{~m}-\mathrm{NBL}$ to $1900 \mathrm{~m}-$ CBL) when compared to in situ RS. The RS, in spite of it being a proven high-precision method, in this experiment was launched only on synoptic times plus an extra at 15:00 UTC. Hence, it did not capture a high-temporal-resolution (like the remote sensors) daily cycle evolution of the height of the PBL, due to the long time interval between launches (each $6 \mathrm{~h})$. While the MWR, WP and the lidar were satisfactory for estimates of the convective phase (CBL) of the PBL, during the nocturnal phase (NBL) these sensors overestimated heights. Additionally, the sodar under- and overestimated the NBL during these periods. 
Table 3. Standard deviation calculated for PBL height measurements of instruments at different intervals of the daily cycle.

\begin{tabular}{|c|c|c|c|c|}
\hline \multicolumn{5}{|c|}{$\sigma-$ IOP3 (15 February to 31 March 2015) } \\
\hline Hours & 00:00-06:00 LT & 06:00-09:00 LT & 09:00-18:00 LT & 18:00-23:00 LT \\
\hline Ceilometer & 29.4 & 57.1 & 67.7 & 64.5 \\
\hline Lidar & $\mathrm{X}$ & 52.1 & 90.3 & $\mathrm{X}$ \\
\hline MWR & 32.3 & 59.8 & 84.7 & 39.8 \\
\hline RWP & 20.4 & 49.2 & 79.4 & 28.6 \\
\hline Sodar & 15.5 & $\mathrm{X}$ & X & 29.0 \\
\hline \multicolumn{5}{|c|}{$\sigma-$ IOP4 (1 September to 15 October 2015) } \\
\hline Hours & 00:00-06:00 LT & 06:00-09:00 LT & 09:00-18:00 LT & 18:00-23:00 LT \\
\hline Ceilometer & 27.4 & 54.7 & 83.6 & 45.0 \\
\hline Lidar & $\mathrm{X}$ & X & $\mathrm{X}$ & $\mathrm{X}$ \\
\hline MWR & 30.5 & 55.0 & 109.7 & 30.6 \\
\hline RWP & 31.1 & 57.9 & 119.6 & 47.8 \\
\hline Sodar & 30.6 & $\mathrm{X}$ & $\mathrm{X}$ & 29.7 \\
\hline
\end{tabular}

The intense EN event of 2015/2016 influenced the development phase of the CBL during the dry season of IOP4, and it had a growth rate of about $15 \%$ higher than the results from IOP2 and a sensible heat flux (responsible for heating the air) that was higher than the standard values for the central Amazon. As a consequence, more intense convective movements occurred and contributed to a stronger vertical development of the layer.

The NBL erosion showed differences between seasons, presenting an erosion time of $2 \mathrm{~h}$ in the dry IOPs (2 and 4), and $3 \mathrm{~h}$ in the wet IOPs (1 and 3). A more detailed analysis of NBL erosion is being elaborated in Carneiro and Fisch (2020).

Data availability. The data sets used in this publication are available at the ARM Climate Research Facility database for the GoAmazon 2014/5 experiment (https://www.arm.gov/research/ campaigns/amf2014goamazon (ARM Climate Research Facility, 2019).

Supplement. The supplement related to this article is available online at: https://doi.org/10.5194/acp-20-5547-2020-supplement.

Author contributions. RGC and GF designed the numerical experiments, and RGC performed the simulations as a part of his $\mathrm{PhD}$. RGC performed data analysis, assisted by GF. RGC and GF prepared the manuscript.

Competing interests. The authors declare that they have no conflict of interest.
Special issue statement. This article is part of the special issue "Observations and Modeling of the Green Ocean Amazon (GoAmazon2014/5) (ACP/AMT/GI/GMD inter-journal SI)". It is not associated with a conference.

Acknowledgements. Institutional support was provided by the National Institute of Space Research (INPE), the National Institute of Amazonian Research (INPA) and Amazonas State University (UEA). Rayonil G. Carneiro acknowledges the Brazilian National Council for Scientific and Technological Development (CNPq) graduate fellowship (140726/2017-9). Rayonil G Carneiro and Gilberto Fisch thank the GoAmazon project group for providing the data available for this study.

Financial support. This research has been supported by the National Council for Scientific and Technological Development (grant no. 140726/2017-9).

Review statement. This paper was edited by Maria Assuncao Silva Dias and reviewed by two anonymous referees.

\section{References}

Acevedo, O. C., Moraes, O. L. L., Silva, R., Fitzjarrald, D. R., Sakai, R. K., Staebler, R. M., and Czikowsky, M. J.: Inferring nocturnal surface fluxes from vertical profiles of scalars in an Amazon pasture, Glob. Change Biol., 10, 886-894, https://doi.org/10.1111/j.1529-8817.2003.00755.x, 2004.

Andrade, N. L. R., Aguiar, R. G., Sanches, L., Alves, E. C. R. F., and Nogueira, J. S.: Net radiation partition in Amazonian forest and transitional Amazonia-Cerrado forest areas, Revista Brasileira 
de Meteorologia, 24, 346-355, https://doi.org/10.1590/S0102$77862009000300008,2009$.

Andreae, M. O., Acevedo, O. C., Araùjo, A., Artaxo, P., Barbosa, C. G. G., Barbosa, H. M. J., Brito, J., Carbone, S., Chi, X., Cintra, B. B. L., da Silva, N. F., Dias, N. L., Dias-Júnior, C. Q., Ditas, F., Ditz, R., Godoi, A. F. L., Godoi, R. H. M., Heimann, M., Hoffmann, T., Kesselmeier, J., Könemann, T., Krüger, M. L., Lavric, J. V., Manzi, A. O., Lopes, A. P., Martins, D. L., Mikhailov, E. F., Moran-Zuloaga, D., Nelson, B. W., Nölscher, A. C., Santos Nogueira, D., Piedade, M. T. F., Pöhlker, C., Pöschl, U., Quesada, C. A., Rizzo, L. V., Ro, C.-U., Ruckteschler, N., Sá, L. D. A., de Oliveira Sá, M., Sales, C. B., dos Santos, R. M. N., Saturno, J., Schöngart, J., Sörgel, M., de Souza, C. M., de Souza, R. A. F., Su, H., Targhetta, N., Tóta, J., Trebs, I., Trumbore, S., van Eijck, A., Walter, D., Wang, Z., Weber, B., Williams, J., Winderlich, J., Wittmann, F., Wolff, S., and Yáñez-Serrano, A. M.: The Amazon Tall Tower Observatory (ATTO): overview of pilot measurements on ecosystem ecology, meteorology, trace gases, and aerosols, Atmos. Chem. Phys., 15, 10723-10776, https://doi.org/10.5194/acp-15-10723-2015, 2015.

ARM Climate Research Facility: Observations and modeling of the green ocean Amazon (GoAmazon), available at: https://www. arm.gov/research/campaigns/amf2014goamazon, last access: 1 June 2019.

Carneiro, R. G. and Fisch, G.: Analyze NBL erosion in the the Amazonia using large eddy simulation model, Bound. Lay. Meteorol., submitted, 2020.

Carneiro, R. G., Fisch, G., Borges, C. K., and Henkes, A.: Erosion of the nocturnal boundary layer in the central Amazon during the dry season, Acta Amazônica, 50, 80-89, https://doi.org/10.1590/1809-4392201804453, 2020.

ECMWF: The 2015/2016 El Nino and beyond, ECMWF Newsletter, available at: https://www.ecmwf.int/en/newsletter/ 151/meteorology/2015-2016-el-nino-and-beyond (last access: May 2019), 2017.

Englberger, A. and Dörnbrack, A.: Impact of Neutral BoundaryLayer Turbulence on Wind-Turbine Wakes: A Numerical Modelling Study, Bound.-Lay. Meteorol., 162, 427-449, https://doi.org/10.1007/s10546-016-0208-z, 2017.

Ferreira, S. J. F., Luizão, F. J., and Dallarosa, R. L. G.: Internal rainfall and rainfall interception in dryland forest subjected to selective logging in Central Amazonia, Acta Amazônica, 35, 5562, https://doi.org/10.1590/S0044-59672005000100009, 2005.

Fisch, G., Tota, J., Machado, L. A. T., Dias, M. A. F. S., Lyra, R. F. D. F., Nobre, C. A., Dolman, A. J., and Gash, J. H. C.: The convective boundary layer over pasture and forest in Amazonia, Theor. Appl. Climatol.. 78, 47-59, https://doi.org/10.1007/s00704-004-0043-x, 2004.

Geisinger, A., Behrendt, A., Wulfmeyer, V., Strohbach, J., Förstner, J., and Potthast, R.: Development and application of a backscatter lidar forward operator for quantitative validation of aerosol dispersion models and future data assimilation, Atmos. Meas. Tech., 10, 4705-4726, https://doi.org/10.5194/amt10-4705-2017, 2017.

Geiß, A., Wiegner, M., Bonn, B., Schäfer, K., Forkel, R., von Schneidemesser, E., Münkel, C., Chan, K. L., and Nothard, R.: Mixing layer height as an indicator for urban air quality?, Atmos. Meas. Tech., 10, 2969-2988, https://doi.org/10.5194/amt10-2969-2017, 2017.
Ghate, V. P. and Kollias, P.: On the controls of daytime precipitation in the Amazonian dry season, J. Hydrometeorol., 17, 3079-3097, https://doi.org/10.1175/JHM-D-16-0101.1, 2016.

Gouveia, D. A., Barja, B., Barbosa, H. M. J., Seifert, P., Baars, H., Pauliquevis, T., and Artaxo, P.: Optical and geometrical properties of cirrus clouds in Amazonia derived from 1 year of groundbased lidar measurements, Atmos. Chem. Phys., 17, 3619-3636, https://doi.org/10.5194/acp-17-3619-2017, 2017.

Holtslag, A. A. M., Svensson, G., Baas, P., Basu, S., Beare, B., Beljaars, A. C. M., Bosveld, F. C., Cuxart, J., Lindvall, J., Steeneveld, G. J., and Tjernström, M.: Stable atmospheric boundary layers and diurnal cycles - challenges for weather and climate models, B. Am. Meteorol. Soc., 94, 1991-1706, https://doi.org/10.1175/BAMS-D-11-00187.1, 2013.

Huang, M., Gao, Z., Miao, S., Chen, F., Lemone, M. A., Li, J., Hu, F., and Wang, L.: Estimate of Boundary-Layer Depth Over Beijing, China, Using Doppler Lidar Data During SURF-2015, Bound.-Lay. Meteorol., 162, 503-522, https://doi.org/10.1007/s10546-016-0205-2, 2017.

Lyra, R. F. D. F., Molion, L. C. B., Silva, M. R. G. D., Fisch, G., and Nobre, C. A.: Some aspects of the atmospheric boundary layer over western Amazonia: Dry Season 1994, Revista Brasileira de Meteorologia, 18, 79-85, 2003.

Kotthaus, S., O'Connor, E., Münkel, C., Charlton-Perez, C., Haeffelin, M., Gabey, A. M., and Grimmond, C. S. B.: Recommendations for processing atmospheric attenuated backscatter profiles from Vaisala CL31 ceilometers, Atmos. Meas. Tech., 9, 37693791, https://doi.org/10.5194/amt-9-3769-2016, 2016.

Macedo, A. S. and Fisch, G.: Temporal variability of solar radiation during the GOAmazon 2014/15 experiment, Revista Brasileira de Meteorologia, 33, 353-365, https://doi.org/10.1590/01027786332017, 2018.

Marengo, J. A. and Espinoza, J. C.: Extreme seasonal droughts and floods in Amazonia: Causes, trends and impacts, Int. J. Climatol., 36, 1033-1050, https://doi.org/10.1002/joc.4420, 2016.

Marengo, J. A., Fisch, G. F., Alves, L. M., Sousa, N. V., $\mathrm{Fu}$, R., and Zhuang, Y.: Meteorological context of the onset and end of the rainy season in Central Amazonia during the GoAmazon2014/5, Atmos. Chem. Phys., 17, 7671-7681, https://doi.org/10.5194/acp-17-7671-2017, 2017.

Martin, S. T., Artaxo, P., Machado, L. A. T., Manzi, A. O., Souza, R. A. F., Schumacher, C., Wang, J., Andreae, M. O., Barbosa, H. M. J., Fan, J., Fisch, G., Goldstein, A. H., Guenther, A., Jimenez, J. L., Pöschl, U., Silva Dias, M. A., Smith, J. N., and Wendisch, M.: Introduction: Observations and Modeling of the Green Ocean Amazon (GoAmazon2014/5), Atmos. Chem. Phys., 16, 47854797, https://doi.org/10.5194/acp-16-4785-2016, 2016.

Morris, V.: Ceilometer Instrument Handbook, Pacific Northwest National Laboratory, USA, 2016.

Neves, T. T. A. T. and Fisch, G.: Nocturnal boundary layer on pastureland in Amazonia, Revista Brasileira de Meteorologia, 26, 619-628, https://doi.org/10.1590/S0102-77862011000400011, 2011.

Neves, T. T. A. T. and Fisch, G.: The Daily Cycle of the Atmospheric Boundary Layer Heights over Pasture Site in Amazonia, Am. J. Environ. Eng., 05, 39-44, https://doi.org/10.5923/s.ajee.201501.06, 2015.

Newman, M., Wittenberg, T., Cheng, L., Compo, G. P., and Smith, C. A.: The extreme 2015/16 el niño, in the context of historical 
climate variability and change, B. Am. Meteorol. Soc., 99, 1620, https://doi.org/10.1175/BAMS-D-17-0116.1, 2018.

Newsom, R. K.: Doppler Lidar (DL) Handbook, Pacific Northwest National Laboratory, USA, 2012.

Nobre, C., Obregón, G., Marengo, J., Fu, R., and Poveda, G.: Characteristics of Amazonian climate: Main features, in: Amazonia and global change. Geophysical Monograph American Ser. Washington, DC: Geophysical Union Books, edited by: Keller, M., Bustamante, M., Gash, J., and Dias, P. S., 186, 146-162, 2009.

Rocha, V. M., Correia, F. W. S., Teixeira da Silva, P. R., Gomes, W. B., Vergasta, L. A., Moura, R. G., Trindade, M. S. P., Pedrosa, A. L., and Santos da Silva, J. J.: Rainfall recycling in the Amazon basin: The role of moisture transport and surface evapotranspiration, Revista Brasileira de Meteorologia, 32, 387-398, https://doi.org/10.1590/0102-77863230006, 2017.

Santos, L. R. and Fisch, G.: Intercomparison between four methods of estimating the height of the convective boundary layer during the RACCI - LBA (2002) experiment in Rondônia Amazonia, Revista Brasileira de Meteorologia, 22, 322-328, https://doi.org/10.1590/S0102-77862007000300005, 2007.

Seidel, D. J., Ao, C. O., and Li, K.: Estimating climatological planetary boundary layer heights from radiosonde observations: Comparison of methods and uncertainty analysis, J. Geophys. Res., 115, 1-15, https://doi.org/10.1029/2009JD013680, 2010.

Shukla, K. K., Phanikumar, D. V., Newsom, R. K., Kumar, K. N., Ratnam, M. V., Naja, M., and Singh, N.: Estimation of the mixing layer height over a high altitude site in Central Himalayan region by using Doppler Lidar, J. Atmos. Sol.-Terr. Phys., 109, 48-53, https://doi.org/10.1016/j.jastp.2014.01.006, 2014.

Stull, R. (Eds.): An introduction to boundary layer meteorology, Kluwer Academic Publishers, USA, 1988.
Tanaka, L. M. D. S., Satyamurty, P., and Machado, L. A. T.: Diurnal variation of precipitation in central Amazon Basin, Int. J. Climatol., 34, 3574-3584, https://doi.org/10.1002/joc.3929, 2014.

Tang, S., Xie, S., Zhang, Y., Zhang, M., Schumacher, C., Upton, H., Jensen, M. P., Johnson, K. L., Wang, M., Ahlgrimm, M., Feng, Z., Minnis, P., and Thieman, M.: Large-scale vertical velocity, diabatic heating and drying profiles associated with seasonal and diurnal variations of convective systems observed in the GoAmazon2014/5 experiment, Atmos. Chem. Phys., 16, 14249-14264, https://doi.org/10.5194/acp-16-14249-2016, 2016.

Tawfik, A. B. and Dirmeyer, P. A.: A process-based framework for quantifying the atmospheric preconditioning of surface-triggered convection, Geophys. Res. Lett., 41, 173-178, https://doi.org/10.1002/2013GL057984, 2014.

Von Randow, C., Manzi, A., Kruijt, B., Oliveira, P., Zanchi, F., Silva, R., Hodnett, M., Gash, J., Elbers, J., Aterloo, M., Cardoso, F., and Kabat, P.: Comparative measurements and seasonal variations in energy and carbon exchange over forest and pasture in South West Amazonia, Theor. Appl. Climatol., 75, 1-22, https://doi.org/10.1007/s00704-004-0041-z, 2004.

Wang, C., Shi, H., Jin, L., Chen, H., and Wen, H.: Measuring boundary-layer height under clear and cloudy conditions using three instruments, Particuology, 28, 15-21, https://doi.org/10.1016/j.partic.2015.04.004, 2016.

Wiegner, M., Madonna, F., Binietoglou, I., Forkel, R., Gasteiger, J., Geiß, A., Pappalardo, G., Schäfer, K., and Thomas, W.: What is the benefit of ceilometers for aerosol remote sensing? An answer from EARLINET, Atmos. Meas. Tech., 7, 1979-1997, https://doi.org/10.5194/amt-7-1979-2014, 2014. 